\title{
Descriptive Analysis of Unmet Need Women
}

\author{
$* 1^{\text {st }}$ Retno Heru Setyorini \\ Doctoral Program in Community \\ Development \\ Universitas Sebelas Maret \\ Surakarta, Indonesia \\ retnoheruhs@gmail.com
}

\author{
$2^{\text {nd }}$ Ismi Dwi Astuti Nurhaeni \\ Faculty of Social and Political Science \\ Universitas Sebelas Maret \\ Surakarta, Indonesia \\ $4^{\text {th }}$ Eni Lestari \\ Faculty of Agriculture \\ Universitas Sebelas Maret \\ Surakarta, Indonesia
}

\author{
$3^{\text {rd }}$ Ari Natalia Probandari \\ Faculty of Medicine \\ Universitas Sebelas Maret \\ Surakarta, Indonesia
}

\begin{abstract}
The increase in contraception use in countries with high fertility rates can prevent about $40 \%$ of all maternal deaths and improve child survival. Knowledge, health education, education level, attitude, husband and family support, previous family planning failure, service quality, and socio-cultural factors influence many unmet needs. This study aims to identify the characteristics, level of knowledge, attitudes, intentions, subjective norms, self-efficacy, and behavior of women of childbearing age couples with unmet needs. The study was conducted at 4,869 unmet need couples. The determination of 369 samples was carried out using the Slovin formula. The instrument used in this study was a questionnaire whose validity and reliability was tested using Pearson's product-moment method. The collected data were analyzed descriptively using SPSS $\mathbf{1 7 . 0 0}$ for Windows. One hundred ninety-six respondents $(46.3 \%)$ aged $20-35,233$ respondents $(63.1 \%)$ were mothers of 2 , and 196 respondents (53.1\%) were respondents with low knowledge. $55 \%$ of respondents have a negative attitude towards contraception, $54.2 \%$ have little intention to use contraception, $50.4 \%$ have low self-efficacy against contraception, $53.9 \%$ have small normative sufficiency, and $\mathbf{4 2 . 5 \%}$ have bad behavior. Couples of childbearing age with little knowledge, low subjective norms, low intention and self-efficacy, and negative attitudes tend to negatively respond to contraceptives.
\end{abstract}

Keywords - childbearing age couples, women, family planning, unmet need

\section{INTRODUCTION}

The world population will increase by 2 billion in the next 30 years, from 7.7 billion in 2019 to 9.7 billion in 2050 . [1] About 6 billion of the current population and more than 8 billion in 2050 are residents of developing countries. Those numbers show an increase in population, which mostly occurs in developing countries. It means that developing countries play a significant role in the community and its relationship with sustainable development. [2]

Indonesia is the fourth most populous country after China, India, and America. Census data for 2012 shows that Indonesia has a population of 244.2 million, with a growth rate of 1.49 percent. Indonesia's population in 2020 reached 272.568 .417 or $3.51 \%$ of the total world population. [3] High population growth will hamper the pace of development in various fields so that the country needs multiple efforts to reduce birth rates.
Family planning is one of the population policies to control the population. The family planning program is designed to improve access to contraceptive use and provide information outreach to enhance the perception of benefits [4]. Increasing contraceptive use and decreasing population growth rates in countries with high fertility rates can prevent about $40 \%$ of all maternal deaths and improve child survival. [5] Population control is needed to balance the population and the world's carrying capacity. [6] An estimated 222 million women worldwide have unmet contraceptive needs. [7] It is a common phenomenon globally, but developing countries have a higher prevalence than in developed countries. [8]

Indonesia Demographic Health Survey data (2017) shows that $10.6 \%$ or 4 million of 36 million childbearing age couples (Pasangan Usia Subur/ PUS) are not served by contraception [9] where $6.30 \%$ of them are in the Special Region of Yogyakarta. [10] Unmet need is a group whose contraceptive needs have not been met. The group includes married (or living together) unmet need childbearing age couples (men and women) who do not want to have children or postpone further births. [11][12]

Indonesia's maternal mortality rate is estimated to increase to 359 / 100,000 live births and continue to grow if the unmet need is not treated11. Unfulfilled needchildbearing age women have a high chance of getting pregnant and experiencing complications during pregnancy, childbirth, and the puerperium. Pregnancy complications caused by abortion due to unwanted pregnancy, pregnancy gap that is too close, giving birth too much, and complexities of the disease during pregnancy. All of which can also cause childbirth problems and childbed complications. [13],[14],[15]

Efforts to reduce Indonesia's unmet needs have not shown maximum results so that the number of unmet needs is still above the national target. Knowledge, health education, education level, attitude, husband and family support, previous family planning failure, service quality, and socio-cultural factors are some factors that influence the high number. [16],[17], [18] 


\section{METHOD}

\section{A. Research Desaign}

This research was conducted using a quantitative approach with a cross-sectional survey design. Based on its purpose, this research is a descriptive study. The study was conducted in Bantul in December 2019 to March 2020 at 4,869 unmet need Childbearing Age Couples who did not want to have more children or postpone pregnancy. This study's scope influences modifying factors, attitudes, subjective norms, self-confidence, and intentions towards behavioral problems using contraceptives.

\section{B. Sampling}

The research sample is childbearing age couples who do not want to have more children and want to postpone pregnancy but do not use contraception, and childbearing age couples who are willing to be respondents. Those who were not ready to be respondents were not included in this study. There were 369 samples involved in this study that were determined using the Slovin formula.

This study's main instruments were questionnaires that the validity and reliability were tested using Pearson's product-moment formula. Validity and reliability tests were conducted on 30 childbearing age couples in the Bantul subdistrict. Validity and reliability tests refer to knowledge, attitudes, subjective norms, self-efficacy, and intentions. After the questionnaires were declared valid and reliable, the childbearing age couples filled the questionnaires. The collected data was then analyzed descriptively.

\section{Ethical Considerations}

Ethical permission was obtained from Sebelas Maret University Surakarta. Informed Consent was obtained from every participant in this study.

\section{RESULT}

The result of this study show indicate that the most age is $20-35$ years, $46,3 \%$, have two children $63,1 \%$, and has a low level of knowledge $53,1 \%$ (table 1 ).

TABLE I. FREQUENCY DISTRIBUTION OF RESPONDENT CHARACTERISTICS BASED ON AGE, PARITY, AND EDUCATION LEVEL

\begin{tabular}{|c|c|c|c|}
\hline No & Variable & Frequency & $\begin{array}{c}\text { Percentage } \\
(\%)\end{array}$ \\
\hline \multicolumn{4}{|c|}{ Ages } \\
\hline 1 & $<20$ years old & 2 & 5 \\
\hline 2 & $20-35$ years old & 196 & 53,1 \\
\hline 3 & $>35$ years old & 171 & 46,3 \\
\hline \multicolumn{2}{|c|}{ Total } & 369 & 100 \\
\hline \multicolumn{4}{|c|}{ Parity } \\
\hline 1 & Primigravida & 93 & 25,2 \\
\hline 2 & Secundigravida & 233 & 63,1 \\
\hline 3 & Multigravida & 40 & 10,8 \\
\hline 4 & Grandemultigravida & 3 & 8 \\
\hline \multicolumn{2}{|c|}{ Total } & 369 & 100 \\
\hline \multicolumn{4}{|c|}{ Education level } \\
\hline 1 & \begin{tabular}{|l|l} 
Elementary/middle school \\
\end{tabular} & 112 & 30,4 \\
\hline 2 & High school & 206 & 55,8 \\
\hline 3 & College & 51 & 13,8 \\
\hline \multicolumn{2}{|c|}{ Total } & 369 & 100 \\
\hline
\end{tabular}

\begin{tabular}{|c|l|c|c|}
\hline 1 & Low & 196 & 53,1 \\
\hline 2 & High & 173 & 46,9 \\
\hline Total & 369 & 100 \\
\hline
\end{tabular}

TABLE II. FREQUENCY DISTRIBUTION OF ATTITUDES, INTENTS, CONFIDENCE, SUBJECTIVE NORMS, AND RESPONDENT BEHAVIOR IN THE USE OF CONTRACEPTION

\begin{tabular}{|c|c|c|c|}
\hline No & Variable & Frequency & $\begin{array}{c}\text { Percentage } \\
(\%)\end{array}$ \\
\hline \multicolumn{4}{|c|}{ Attitude } \\
\hline 1 & Negative & 203 & 55 \\
\hline 2 & Positive & 166 & 45 \\
\hline \multicolumn{2}{|c|}{ Total } & 369 & 100 \\
\hline \multicolumn{4}{|c|}{ Intention } \\
\hline 1 & Low & 200 & 54,2 \\
\hline \multirow[t]{2}{*}{2} & High & 169 & 45,8 \\
\hline & Total & 369 & 100 \\
\hline \multicolumn{4}{|c|}{ Self-efficacy } \\
\hline 1 & Low & 186 & 50,4 \\
\hline 2 & high & 183 & 49,6 \\
\hline \multicolumn{2}{|c|}{ Total } & 369 & 100 \\
\hline \multicolumn{4}{|c|}{ Subjective norm } \\
\hline 1 & Low & 199 & 53,9 \\
\hline 2 & High & 170 & 46,1 \\
\hline \multicolumn{2}{|c|}{ Total } & 369 & 100 \\
\hline \multicolumn{4}{|c|}{ Behavior } \\
\hline 1 & $\mathrm{Bad}$ & 212 & 57,5 \\
\hline 2 & Good & 157 & 42,5 \\
\hline \multicolumn{2}{|c|}{ Total } & 369 & 100 \\
\hline
\end{tabular}

Table 2 shows that of the 369 respondents, 55\% of respondents had a negative attitude towards contraception, $54.2 \%$ had low intention to use contraception, 50.4\% had low self-efficacy against contraception, $53.9 \%$ had small normative sufficiency, and $42.5 \%$ have bad behavior.

TABLE III. CROSS TABLE ON THE INFLUENCE OF KNOWLEDGE LEVEL, ATTITUDE, SELF-EFFICACY, SUBJECTIVE NORMS AND INTENTIONS ON RESPONDENT BEHAVIOR IN THE USE OF CONTRACEPTION

\begin{tabular}{|c|c|c|c|}
\hline \multirow{2}{*}{ Variable } & \multicolumn{2}{|c|}{ Behavior } & \multirow[t]{2}{*}{ Total } \\
\hline & Bad & Good & \\
\hline \multicolumn{4}{|l|}{ Education level } \\
\hline Low & 122 & 74 & 196 \\
\hline High & 90 & 83 & 166 \\
\hline Total & 212 & 157 & 369 \\
\hline \multicolumn{4}{|l|}{ Attitude } \\
\hline Negative & 137 & 66 & 203 \\
\hline Positive & 75 & 91 & 166 \\
\hline Total & 212 & 157 & 369 \\
\hline \multicolumn{4}{|l|}{ Self-efficacy } \\
\hline Low & 130 & 56 & 186 \\
\hline High & 82 & 101 & 183 \\
\hline Total & 212 & 157 & 369 \\
\hline \multicolumn{4}{|c|}{ Subjective norm } \\
\hline Low & 140 & 59 & 199 \\
\hline High & 72 & 98 & 170 \\
\hline Total & 212 & 157 & 369 \\
\hline \multicolumn{4}{|l|}{ Intention } \\
\hline Low & 142 & 58 & 200 \\
\hline High & 70 & 99 & 169 \\
\hline Total & 212 & 157 & 369 \\
\hline
\end{tabular}

Table 3 above shows that 122 of 369 respondents had low knowledge and lousy behavior regarding contraceptives. One hundred thirty-seven respondents indicated negative attitudes and bad behavior towards contraceptives. One 
hundred thirty respondents had low self-efficacy and practice, which is not suitable for contraception. One hundred forty respondents have small subjective norms and show bad behavior towards contraception. One hundred forty-two respondents have a low intention and bad behavior towards the use of contraception.

\section{DISCUSSION}

Most respondents aged 20-35 years old and have two children. The best age for childbirth is 21-35 years old. [19] Women aged 21 years old are considered to have maturity in emotions, personality, and social. Women less than 21 years old have a uterus and hips that are not fully developed to experience labor difficulties. On the other hand, women aged over 35 years have a high risk of pregnancy. Every married couple is recommended to have only two children. The minimum gap between the first and second pregnancy is two years. The difference between pregnancies that are too close can increase the risk of pregnancy. The maturity of age and number of children is not directly proportional to couples' knowledge about contraception.

The results showed that many respondents had low levels of contraceptive knowledge despite having more than one child. They also show bad behavior towards contraception. Some efforts by the government to increase awareness about family planning are strengthening Communication, Information, and Education (IEC). IEC has proven effective in increasing knowledge about family planning and contraception in most childbearing age couples (98\%). However, their high level of knowledge about family planning and contraception did not increase their desire to become family planning participants at $57.9 \%$ (2012 IDHS). The community also still has a low level of knowledge on population issues at $34.2 \%$. [20]

Many factors affect one's level of knowledge. These factors are education, information, experience, and age. [21] Humans aged 36-45 years have a good comprehension and thinking ability to increase their knowledge. The results of this study indicate that the right level of experience does not follow age maturity. Physiological and psychological factors can inhibit the learning process in adult humans, such as visual impairment, hearing loss, and educational background, which can reduce one's ability to think and work within a specified time. [22]

The experience dramatically influences knowledge; the more experience, the more someone's knowledge about it. [21] This research shows that most respondents who have experience with two children do not have enough knowledge due to a lack of experience and information about contraception.

This study indicates that the majority of respondents have low attitudes, intentions, and subjective norms. This research was conducted on unmet need childbearing age couples. Their reluctance to use contraceptives is influenced by several factors that influence attitudes, subjective norms, self-efficacy, and intention to use them. Her husband's awareness and support influence a woman's desire to use modern contraceptives. [23] Stein assumed that fertility goals are affected by couples' decisions, which are more influenced by the husband's opinions. [24] The transition to having children results from an interplay of interacting processes and varying degrees of decision. Husband support through appropriate communication can help women identify their husbands/partners. [25] Umi and Sumini [26] stated that the husband's support in family planning programs could increase contraceptive use prevalence.

Women's unmet needs arose because of social factors. This factor is one of them derived from the view of the husband. The lack of trust in Western medicine, the desire to have large families, and low socioeconomic status also significantly influence. On the women's side, there was also an assumption that health service providers did not meet the criteria. It was also triggered by a lack of awareness and understanding of contraception. Finally, the cause is the perceived risk posed by risks caused by significant contraception. [27]

This study also shows that respondents with positive attitudes towards contraception have good behavior towards the use of contraceptives. Respondents with moderate selfefficacy have good practice to use contraception. Respondents who have an average level of subjective norms have a positive attitude towards contraception. Subjective norms improve attitudes and self-efficacy in the use of contraceptives.

According to the framework of the Theory of Reason Action (TRA) [28], intention determines actual behavior. The TRA model shows two essential factors that determine a person's behavioral purposes: (1) attitudes toward behavior and (2) subjective norms. Individual opinions represent one's personal beliefs and feelings about specific actions. People who believe that good ethics leads to positive results will behave well toward that behavior. On the other hand, someone who thinks that bad behavior leads to adverse effects will be unprofitable in practice. Based on the TRA model, attitudes toward behavior are determined jointly by someone's belief that the action leads to specific outcomes.

Subjective norms reflect a person's social perception of the pressure to do or not perform the intended behavior. Strong influence occurs when the strength comes from someone who knows the decision-maker personally, while the weak impact is caused, and the pressure comes from someone who is not yet recognized by the decision-maker. [29] It means that the harder a person thinks about behavior, the higher its intention. [28] Subjective norms are influenced by two things, namely normative beliefs and motivation, and it is based on the expectations of significant figures in an individual's life. The second factor is related to the motivation to fulfill the desires and needs of essential statistics.

\section{CONCLUSION}

Childbearing age couples with good attitudes, intentions, subjective ethical norms, and self-confidence to use contraceptives do not necessarily have the right attitude toward contraception. The couples who have more than one child do not necessarily have good knowledge of contraception. Provision of clear information must still be given to Childbearing age couples by involving husbands and other parties who positively influence making decisions regarding contraceptives. 


\section{ACKNOWLEDGMENT}

The authors would like to acknowledge their sincere thanks to the Ministry of Research, Technology, and Higher Education of the Republic of Indonesia for providing postgraduate education scholarships (BPPDN).

\section{REFERENCES}

[1] U. D. of E. and S. A. Nations, "World Population Prospects 2019 : Highlights," no. June, pp. 2-3, 2019.

[2] T. Güney, "Governance and sustainable development: How effective is governance? Governance and sustainable development: How effective," vol. 8199, no. November 2016

[3] Worldometer, "Indonesia Population (2020) - Worldometer," 2020. [Online]. Available: https://www.worldometers.info/worldpopulation/indonesia-population/. [Accessed: 09-Jul-2020].

[4] J. Cleland, "Population, Poverty, and Sustainable Development A Review of the Evidence," no. June 2011.

[5] J. Cleland, A. Conde-Agudelo, H. Peterson, J. Ross, and A. Tsui, "HP Family Planning 2 Contraception and health," vol. 6736, no. August 2014, 2012.

[6] T. Malthus, "An Essay on the Principle of Population," 1998.

[7] P. Patel et al., "Tracking official development assistance for reproductive health in conflict-affected countries : $2002-2011$," no. February, pp. 1-12, 2016.

[8] Population Reference Bureau, "2012 World population data sheet," Www.Prb.Org, pp. 1-20, 2012.

[9] BKKBN, "Laju Pertumbuhan Penduduk 4 Juta Per Tahun," 2016.

[10] Badan Pusat Statistik, "Persentase Unmet Need KB (Kebutuhan Keluarga Berencana/KB Yang Tidak Terpenuhi) Menurut Provinsi, 2012 dan 2017." [Online]. Available: https://www.bps.go.id/dynamictable/2018/06/05/1422/persentaseunmet-need-kb-kebutuhan-keluarga-berencana-kb-yang-tidakterpenuhi-menurut-provinsi-2012-dan-2017.html. [Accessed: 09-Jul2020].

[11] BKKBN, "Gerakan Meniadakan Unmet Need KB - Perwakilan Bkkbn D.I. Yogyakarta." [Online]. Available: http://yogya.bkkbn.go.id/gerakan-meniadakan-unmet-need-kb/. [Accessed: 09-Jul-2020].

[12] WHO, "Unmet need for family planning," WHO, 2016.

[13] N. R. Council, Reducing Maternal and Neonatal Mortality in Indonesia: Saving Lives, Saving the Future. The National Academies Press, Washington DC, 2013.

[14] S. A. Adedini, C. Odimegwu, E. N. Imasiku, and D. N. Ononokpono, "Unmet Need for Family Planning: Implication for Under-five Mortality in Nigeria," vol. 33, no. 1, pp. 187-206, 2015.

[15] L. McDougall, O. M. R. Campbell, and W. Graham, "Maternal Health An Executive Summary for The Lancet's Series," Lancet, vol. 388, no. 10056 , pp. 1-8, 2016
[16] M. Palamuleni, "Determinants of Unmet Need for Modern Contraception and Reasons for Non-use among Married Women in Rural Areas of Burkina Faso Determinants of Unmet Need for Modern Contraception and Reasons for Non-use among Married Women in Rural Areas of Burkina Faso," no. April 2014, 2016.

[17] A. A. A. Ali and A. Okud, "Factors affecting the unmet need for family planning in Eastern Sudan," 2013.

[18] T. C. Okech, N. W. Wawire, and T. K. Mburu, "Contraceptive Use among Women of Reproductive Age in Kenya's City Slums," Int. $J$. Bus. Soc. Sci., vol. 2, no. 1, pp. 22-43, 2011.

[19] Kementerian Pemberdayaan Perempuan Dan Perlindungan Anak, "Wanita Perlu Pahami Kesehatan Reproduksi." [Online]. Available: https://www.kemenpppa.go.id/index.php/page/read/31/573/wanitaperlu-pahami-kesehatan-reproduksi. [Accessed: 09-Jul-2020].

[20] [20] BKKBN, "Rencana Strategis Badan Kependudukan Dan Keluarga Berencana Nasional Tahun 2015-2019," Badan Kependud. dan Kel. Berencana Nas., vol. 1, no. 1, pp. 1-43, 2015.

[21] [21] M. F. Chan, "Factors affecting knowledge, attitudes, and skills levels for nursing staff toward the clinical management system in Hong Kong," CIN - Comput. Informatics Nurs., vol. 27, no. 1, pp. 57-65, 2009.

[22] [22] BPPP Lembang, "Belajar Orang Dewasa," 2017. [Online]. Available: http://www.bbplembang.info/index.php/arsip/artikel/artikel-manajemen/1049-belajarorang-dewasa. [Accessed: 09-Jul-2020].

[23] [23] E. E. Ezeanolue et al., "Impact of male partner' s awareness and support for contraceptives on female intent to use contraceptives in southeast Nigeria," BMC Public Health, pp. 1-6, 2015.

[24] [24] P. Stein, S. Willen, and M. Pavetic, "Couples' fertility decisionmaking," Demogr. Res., vol. 30, no. 1, pp. 1697-1732, 2014.

[25] [25] N. Prata, S. Bell, A. Fraser, A. Carvalho, I. Neves, and B. Andrade, "Partner support for family planning and modern contraceptive use in Luanda , Angola Partner support for family planning and modern contraceptive use in Luanda, Angola," vol. 21, no. June, pp. 35-48, 2015.

[26] [26] U. Listyaningsih and S. S. , Sumini, "Unmet Need: Konsep Yang Masih Perlu Diperdebatkan Unmet Need: the Debatable Concept," vol. 24, pp. 72-90, 2016.

[27] [27] K. Ackerson and R. Zielinski, "Factors influencing use of family planning in women living in crisis affected areas of SubSaharan Africa: A review of the literature," Midwifery, vol. 54, no. January, pp. 35-60, 2017.

[28] R. J. Vallerand, P. Deshaies, J. P. Cuerrier, L. G. Pelletier, and C. Mongeau, "Ajzen and Fishbein's Theory of Reasoned Action as Applied to Moral Behavior: A Confirmatory Analysis," J. Pers. Soc. Psychol., vol. 62, no. 1, pp. 98-109, 1992

[29] P. W. M. A. J. B. COHEN, "An Examination of the Fishbein-Ajzen Intentions Model' s Concepts and Measures," J. Exp. Soc. Psychol. 17, 309-339 (1981), 1981. 